The Committee for the International Exposition of 1892, or the City of New Yokk.

\title{
COMMITTEE ON LEGISLATION.
}

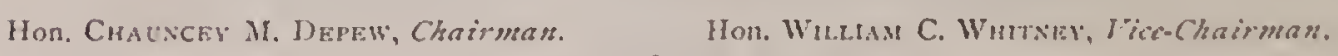
Whilam E. D. STokes, Secretary.

\section{TTKK OF \\ William E. D. Stokes,}

Secretary of the Commitle on Legislation,

To

The Chamber of Commerece and Industry of Louisianla,

READ AT THEIR MEFTING AT XEW ORIEAXS

OX TII:

$13 T H$ NOVEMBER, 1889,

- On the question of the Location of the International

Exposition.

New Yorris Candidacy for the World's Fair of 1892 $\mathrm{Br}$

\section{Hon. Whr. Waldorf Astor,}

Vice-Chaimun of the Committer on Site and Buildings.

F.x U. S. Minister to Italy.

Irrom the December number, by permission of the Cosmopalitum,

IN ANSIIER TO

Senator FARWELI,'s Argument for Chicago, in that magazine in November.

With the Letters of Mr. Stokes

read at the meetings of the Board of Trade of Providence, R. I., on the $7^{\text {th }}$ and $15^{\text {th }}$ of October, I 889 , and their action thereon. 


\section{The Committee for the International Exposition}

$$
\text { of } 1892 \text {. }
$$

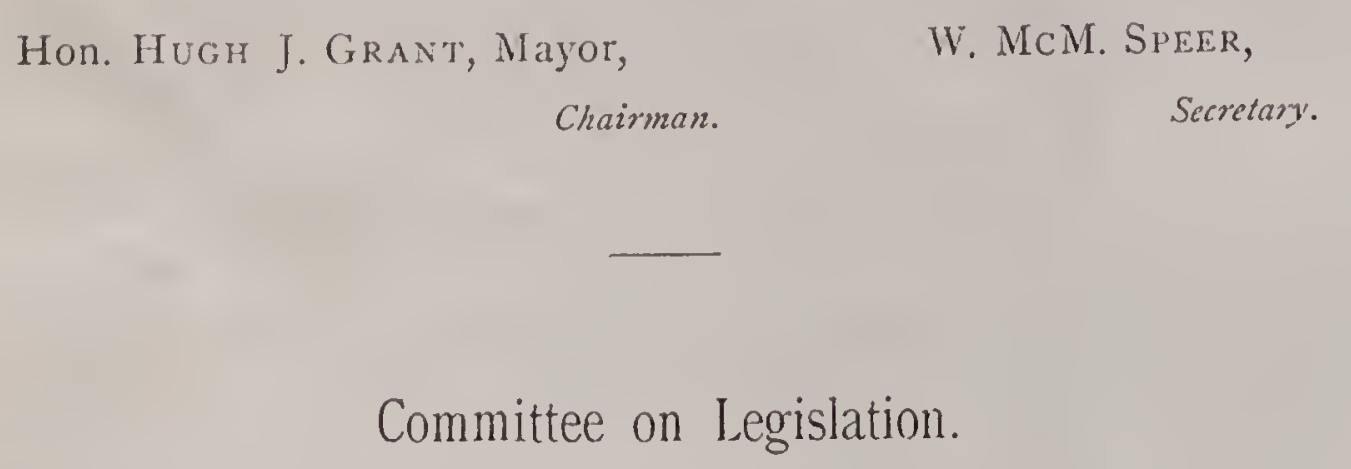

Hon. Chauncey M. DePew, Chairman. Hon. Wh. C. Whitney, Vice-Chairman.

Wiliain E. D. STOKEs, Secretary.

EDWARD M. AMMIDOWN.

DANIEL F. APPIFTON.

IIon. Jolin C. Calmoun.

Francis IV. Cheney.

Hon. Alonzo B. Corneil.

Hon. Chauncey M. Dielliw.

Hon. Franklin Edson.

Hon. Joki B. ERHARdT.

Hon. Wm. M. EVARTS.

Hon. Ilamilton Fisir.

HON. ABRAM S. HEWITY.

JOSEPH LIEBMANN.

\begin{abstract}
William R. MAYER.
Herman S. Mendelson.

Hon. Warner Miller.

Hon. LeVI P. MOKTON.

Hon. Thomas C. Plat'T.

Hon. ElHU RooT.

Gen. IVm. T. Sherman.

Anbrose Siow.

WM. E. 1). STOKES.

James W. TAprin.

francis B. Thurber.

HORACE WHITE.
\end{abstract}

Hon. WM. C. WHITNEY.

Executive Commtte: The Chairman, Vice-Chairman, Secretary, Messrs.

Cahioun, Cornell, Hewitt, Mhlfer, Platr, Root, Thurber.

W. E. D. Stokes, Secretary, i 46 Broadway, N. Y. 


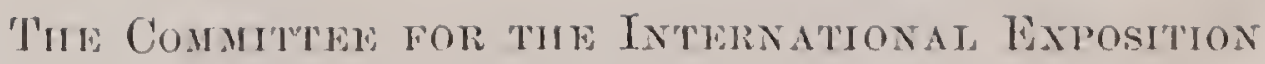
OF 1892 of THF City of NwW YoRk.

\section{COMMITTEE ON LEGISLATION.}

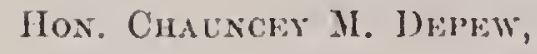
Chairman.

Witidain E. D. Stokes, Secretary.

T'o the Chamber of Commerce and Industry of Louisiana:

Genthemlex: His Honor, Mayor Grant, of this city, has referred to the Committee on Legislation the letter from Hon. A. W. Crandell of your body, dated 31st October, 1889, requesting information from us as to the claims of this city, in contrast with those of Chicago, for the location of the Exposition, to which, under the direction of Hon. Channey M. Depew, Chairman of this Committee, I have the honor to respond.

Since the discussion about the location of the Exposition of 1892 was opened at Providence, in October, and since the defeat of Chicago in the first pitched battle of her own planning, her claims have been put forth by her citizens mores vigorously than ever. Her faith in the old motto, "Beaten. in the battle but noc in the var," is distinctively American: but she has offset that defeat by proclaiming a victory in her bulletins.

'These claims are on three principal grounds:

1st. That it is her turn for a great gathering of the people of the world. Philadelphia, New York and New Orleans have held great Centennial Celebrations, while the Northwest, of which Chicago is the chief city, has had none. 
21. 'That it is a great, growing, healthful, beantiful cify, with ample accommodations, and is itself an expression of the wonderfnl genius of the nation.

31. That it is a great railroad centre, and more readily accessible from all parts of the comntry than any other city within it.

We are as proud to admit these claims as Chicago is to assert them; yet they do not lise to a challenge of the superiolity of New Tork, in all these respects.

The World's Fair at Pliladelphia, in 1876, is the only one to be compared with the proposed Exposition; yet it commemorated a local event, the Declaration of Independence. The New York celebration in May, 1889, lasted for' three days only in honor of the inauguration of the first President-a local event. The fair at New Orleans was for the colton interest. Neither of these were International, nor were foreign powers invited.

Thime is long enough and the world is large enough for Chicago to have her little turn, even if she is not favored now. Let her contemplate the beauty and glory she will attain, in another century or less, and discover some other event more worthy of her honor than the sailor Columbus, who was not an inland explorer like the Jesuit fathers. or Marquette and La Salle, to whom she should pay homage. Like Cinderella she will be a princess, and when she has reached the maturity of her beanty the whole world will turn out to throng her court. We are not considering turns now, but the fit location for the first International. Ixposition, this country will ever really hold.

The people of New York have no local jealousy. They concede in the fullest measure the winsome beanty and the advantages of Chicago, although she is not over her youthlnl ways. The pre-eminence of New York is so marked, it is due so much to the concentration of natural forces and it is so consolidated and certain, that these questions of 
"omparison do not inte:est us. We are self-depreciating lather than boastful. That stage of our youth has passed. We admit some narrow and poorly paved streets, some past defects in municipal gorerument. We do not palliate, but with a strong hand we remedy them. Om pride is in the growth and prosperity of the whole country, and we strive to promote it in every city and town. If they had left anything unsaid, we would take up her praises and exalt Chicago. We maintain a metropolitan and cosmopolitam spirit, and shelter all, rich or poor, who seek our altars. The futnre of New York rests mpon its mnsurpassed liarbol, and its broad livers which open its waterways to the East. and westward through the Lakes reach the fertile prairies in the heart of the Continent. 'The magnificence of this river scenery is the admiration of the world, for no other great city has snch scenery within sight. One phase of natmal beauty is conceded to Chicago, "her broad expanse of prairie, and not yet salted sea," al though they are "salting" it rapidly. She is waiting for the ship canals to St. Lonis, or to the St. Lawlence. A dead level does not inspire the poetry of Nature, yet she possesses all the natural beauty that anything so flat can have. Men camnot live and die in Chicago. They cry out, as did Klopstock, "Oh! for the ocean, the ocean!" and they repeat it every summer.

As the centre of the Northwestern system, with its two score of railloads radiating over the plairies, filling them with towns and cities, and farms the richest in the world, Chicago illnstrates the great interest New York has taken in her adrancement. We have given the strongest proofs of our faith by the investment of money there. She speaks of the population she can collect within a radius of 500 miles, but it is not greater than we can collect within a radius of 250 miles, and excluding the ocean over an area only one-sixth as large.

Frery railroad system comes to New York. We have driven our railroads westward over mountain passes and 
deep valleys, have pierced the Alleghanies, and on their western slopes have built up many railroad centres that carry on onr main lines to the northwest, the southrest and westward to the Pacific. The movement of travel from all sections to this City is universal and incomparable, lor Chicago ranks as one of our tributaries. In addition, we have the great bulk of foreign comnerce which touches only the sea and gulf coast, for Chicago has not yet made herself a seaport.

It is no wonder that Chicago is proud of her matchless growth, and that it gives hel undamted conage, even in a contest beyond her strength. Like the Scotch Donglas, the forefather of her own statesman, her leaders raise the ary, as they rush on to defeat, "Forth! Heart of Bruce, as "thon were wont, and Douglas will follow thee or die."

There are two questions at the root of this matter.

1st. Is this Exposition to be a National or Intemational one?

2d. What is its real end and purpose?

On these points the idea of Chicago is radically distinct from ouls, and as distinctly narrow. She contemplates an Exposition that "shall be distinclly and grandly Amerierı," and promises an Agricultural Exhibit of lumber, grain, farm, dairy and hen products, farm machinery, cattle and minerals. This is not an International Exposition. Her great orators, taking an illustration from their life on grip-cars, tell us that "Chicago has never grappled with any great enterprise in vain," and to prove it, amnonnces that the decision against them at Providence, the first time they provoked an issue, was "most satisfactory to Chicago." Are they really bent on following the leading of Providence, and coming out for New York?

'They have sent out their circulars and appeals to every one within their business connections, with special points to each 
profession and trade. They have organized debates and discussions. 'Their citizens have been divided into Committees, according to the comnty of their origin in other States, and send nrgent calls to their home districts. They have sought pledges from every member of Congress, and reckoning polite phrases as promises, will have a groor lot. of "chickens counted before they are hatched" fo cxhibit among their farm products. They do it on husiness principles. send ont drummers and solicit rotes in Congress as they do cnstomers. In all these docmments they hold but one idea. Tt is repeated orer and again in the same language. It is the common idea of the fairs held, every year in every commly and every state, where bigness is the nurk of excellence-tall cornstalks, heary cattle, overgrown calves, big pumpkins, fat hogs and fast horses. To enlarge one of these fairs to an inconvenient size will not make it grand or International. 'There is not rariety enongh. 'T'oo many cattle, too many pumpkins, too much pork and beans become monotonous. These thing belong to an early stage of civilization-such a fail as might have been held in the plains of Andalusia fonr centuries ago. They are very common. Except in the great West, people do not travel far from home to see them. They would rather come to New York for relief from that nonotony, lor the atructions that are peculiar to and always in New York, and every year, all who ean do so, are sure to come.

It is true that they specially invite engineers, and as there is little engineering. in a flit country with shallow streams, they offer them the inducement of "an excursion "from and to the Atlantic and Pacific seaboards," so that they may see the Brooklyn bridge, and the bridges and the tumnels across the Hudson and the Harlem.

Beyond this they go on and deyreciate any other kind of exhibit. They say plainly that " the attations of $n 0$ city " in America will induce people of other nations to attend "our exposition," because they have larger and finer cities of their own. They ridicule "any benighted tomist who 
"would cross the ocean to inspect our feeble imitations of "foreign galleries." They even belittle the number who will cross the ocean to attend. The capacity of the ocean steamers "would not adnit of a hundred thousand foreign"er's visiting our World's fair"; "their whole number not "equaling one average day's attendance"; forgetting that, if it were true, this small number would be the elite in rank, oflicial distinction, wealth, enterprise and skill. Such pains do they take to repel the idea of an International fair, and to limit it to "the natural products of the "country, to the fertile fields, and to Chicago as the great "agricultural centre." Thus do they restrict the world they invite to the leanness of their own larder. As the Chicago hotel keeper said, laying his pistol and the hash plate on the breakfast table, "Gentlemen, I hear you all want hash "for breakfast, and you shall have hash!"

Then, with an iteration that to a Chicago ear is grateful, we hear descriptions of a "Windy City" on the west shore of a lake which all know to be flat and low, with all atmosphere filled with smoke and soot, and an open slimy sewer running through it, into a "lake which is at once her" reservoir "and refrigerator." Yet this they describe in terms to persmade us that it is Jerusalem the Gollen, a city set upon a hill, and not one of the cities of the plain, lained on, blown on, and desolate, without even salt enough to save it.

One would suppose that no other city was free from sunstrokes, and that they had a monopoly of fresh air and pure water, though these may be a marvel in that low comntry. New York, with its breezes alternating from the Atlantic to the Alleghanies, and its water from mountain springs led thirty-three miles to the city by an aqueduct twenty feet in diameter, through the solid rock 300 feet below the surface, holds in slight esteem a water supply drawn from a lake into which is poured the sewage of a whole city and its comntless factories. Four miles of 
distance, in an off-shore current, is no better barriel ag aninst impurity than they have found two miles to be. Their' irrepressible enthusiasm is commendable, thongh it makes them credulous. They should remember that these tales are not impressive away from home. We shall not try to rival them in appeals to all parts of the combry, nor in getting up a trust in wind. IVe camnot rival them in dymamiters and bomb-throwers. What attracts these: Nihilists as soon as they land at once to Chicago will deter the most distinguished foreign visitors from al)proaching her. In this respect the atmospliere of Chicugo is very difterent from New York. Why do they not make their Fair the celebration of the 210th anniversary of the landing of La Salle, in January, 168\%, in the swamps at the mouth of their river. He found it the best portage to the Illinois and the Mississippi. He was their first discoverer and visitor, and described its stomy waters and wintry gales, but did not remain there longer than a day.

Their writers do not appreciate Columbus beyond the fictitious story of the egg, which fastens on their farm yard fancies. He was no more than a salt water sailor, and did not refer to them with the praise to which they are accustomed from their barnyard fences every morning. Here is the description of Columbus:

"They then saw a band of Indians, who fled. The Chuis" tians to get some information ran after them, but could "only overtake a young woman, who was imperled by her "large feet. She came from the far interior" and had a differ" ent appearance. She had a plate of gold hanging at her " nose. She was carried to the Admiral (Cohmbus). She " cried, 'Sheliongon, Shekongon, Shekougou.' He gave "her several baubles, as bells, a glass and a piece of Portı"guese pottery. He sent hel back, without the least dis"gust offered to her, ordering three Indians and three

"Christians to take her to her own Company."

We must admit that we have not an "Anditorimm"; but for years we have had the Cooper Union and the Metropolitan 
Opera Iouse, and will soon lave the Madison Square garden, covering two acres, and reaching towards the sky; and we have here one of Columbus fair danghters, as old as the City itsell, Columbia College.

New York is accustomed to crowds. As the centre of three and a half millions, one seventeenth of the total population, within hall an hour of the City IIall, it is itself a crowd, with ample room to entertain another million or so, growing greatly in size and in facilities for internal travel every year. This great concentration of population is essential, for the success of the Fair demands 200,000 visitors earch day.

Your own fellow member Colonel J. C. Wickliffe put it arlmirably at yon meeting on the 30th October', as reported in the Piccuyune.

"As a proof of the friendly feeling of New York he calls "attention to Governor Hill's speech to the Pan-American "delegates putting in a good word for the South and "being instrumental in bringing about the supplemental " jonmey here. New York thinks of the South always, " and not only when it wants something.

"If the Paris Exposition had been held at some intelior: " city of France, it would not have been the same success.

"Paris is the best known city. In the same way New

"York and New Orleans are the best known cities of

"America, because of their cosmopolitan claracter. New

"York has vast hotels, amusements and other facilities.

"If New York is tilled up, it has Brooklyn, Jersey City "and Philadelphia to fall back upon. If Chicago is filled

"up, there is no other place to go to, except to lodge the

"visitors in a dry goods box and to hoard them at a pea-

"nut stand. On sentimental grounds he opposed Chicago " -als the plate where the dinerican flig contd be hissed "withont the hisser being chastised. If it is to be an "American Exposition, he wanted it held where the "American flag is respected, and in the metropolis of "America." 
It will be tor Congress to decirte which rity will have this Tntermational lair', and the decision will not be controlled by the amount of money the dities laise. Other considerations will prevail-where the foredgu exhibits can most combeniently he received. where om own mamn. factmers can must conveniently present their goods. and our designers and inventors stmely new ideas to be pur to a practical nise.

Chicago is not the only instance of rapid growth in this comntry. There are other eximples quite as notable. Birmingham and Asherille can cham the location on the same gromeds. Nor is Chicaso the only rity that has burned down in wook and been built mp in stone. pratiseworthy ats that is. Atlanta has done it. and so has Bostonl, thongl Boston excited the jealonsy of Chicago becanse, while fewer square miles were devastated, more millions in value were destroyed.

'The lavish expenditure to detend hel clains shows that some great local advantage must be contemplated. That will not influence the decisions, when the question is, which is the best location? in faror of the city which wants it most and is fitted lor it the least. It will not influence foreign exhibitors to send their goods there. They want the best place.

The great value to us in the Exposition is what our inventors and designer's acquire from other nations. Columbus had all the scientific knowledge of his day. It was a scientitic induction that the eastem continent must be balanced by a western, that convinced him that there was something to discover west of the Atlantic, and this same search for knowledge prevals at the present day, ami is to be encomaged by the linil.

The points on which Chicago rests her chams remind one of Commodore Vanderbilt. After serutinizing arefnlly a lot of horses from which he was expected to select one. he began praising the mane and tail of a young roum mare. "Why," asked the jockey, "do you speak of her mane 
and hor lail!" "Becanse," said the Commodore, "it is the only thing I see in her to admire."

We think but little of these arguments, and rely on the absolute strength of the featme of Internationality and the cool deliberate judgment of Congress, without the aid of reception rooms and loaded sidebonds to greet the member's as they arrive at Washington.

The plan of Chicago does not rise to the level of the idea of New York. New York starts from a higher plane, beneath which Chicago can exert and glorify herself without interference. She leaves to us the broader view of an International exposition, which weare ready to carry ont.

In 1492, the Continent of Africa had been circumnavigated and the northern seas explored. The East Indies had also been reached throngh the Red Sea. Maps and globes had been male and sold. They showed a blank, west of the Atlantic, toward which the shores of India were extended. Reaching India by crossing this vacancy and sailing westward had been considered for centuries. The sailor's were brave, but the small vessels were not fitted to contend with the gigantic storm winds of the Equinox, and superstition filled the boundless sea with unknown temors. False Science, the overwhelming influence of the Church and the folly of Kings forbade all enterprise. Columbus urged his clain, for half a life time, before he prevailed, and then gained it, not from the comrage of a man, but from the sympathy of a woman, the woman's lieart won, as ever, by the danger's he had passed and the greater danger's he longed to encounter.

'T'o the Old $1 \mathrm{~W}$ orld, the discovery opened new fields of adventure and wealth. Population overflowed into it, but they left behind human tyranny over human thought and action. The same people from Western Europe grew up on this side in native freedom in hardships and prosperity, and on the other side the Athantic, under their old despot- 
isms. Wre have justified and demonstrated our freedom, have revolted at their domination, and have brought them slowly to accent and believe in our principles. This is the lesson of this quadri-centemial and this is the cross it will hold up for the future to the whole world, with larger meaning in the motto, In hoc signo vinces, thin it ever contained before. This is what Columbus predicted, and called on us to celebrate.

'This broader view is natural to New York. It is International and for the world. It is not National, nor for this country only. 'This kind goes not forth by boasting. We invite them to see the moral and material results of our principles. England, France, Holland, Sweden, and Spain, who once owned these Wrestern Continents, see the greater successes of their children. If they seek the causes they are not concealed. They can find them in a word, FrwsDom, the uppermost word in all this land.

Between this continent and the Old World New York is the portal, not the toll-gate. It fitly represents the spirit of the country ; its liberty, equality and fraternity is extended to all nations. The wealth of the world enters here, and with it the men of courage and enterprise who wield it, who seek new discoveries and new wealth, as of old, in our generous resources. 'This discovery is going on year by year.

Chicago leaves it also for us to look into the future. 'The young and energetic men of this day have a future to look forward to. At the beginning of the 2oth Century its destiny will be in their hands.

"No pent-up Ulica contracts our powers,

was once a motto of New York, as it his come to-day to be of Chicago. 'The Continent, of which Chicago is the centre and the pride, has been compassed. New York has passed beyond this sentiment and for its dominance now

"Thenns ore the wistrul limit of the World." 
The eluse of this Century sees a great change orer the fice of the earth. Steam and electricity have done it. The hand of man grasps the whole world, and holding it within reach, his nerve and will-power. and his knowledge, are hecoming immediate and instantaneous. 'There are no Jonger any undiscorered regions, nor mnknown dark Continents. Africa is parcelled ont. The islands of the sea are appropriated. The waste brearths of onl own country arm surveyed and fenced in, and laid out into States. 'The birds of the air, the beasts of the field, and Leviathan and the fishes in the sea are no longer under man's dominion to destroy, bnt to protect and to count as the stock on his farm. 'l'he fair face of natme must be, as the Yellowstone Park, ciremuscribed from man. This description will not be found overstated at the beginning of the next Century.

From this post, at the great ontlet to the four seas, this is the dominion toward which New York looks, not for itsell, but for the country, as the sentinel on the relge of the camp), to spread its freedom, its principles, its influence and its jusperity orer the whole earth, and to gain for it the moral and peaceful ascendency which the triumph of our" principles will ensure. "For all that is not behind us "is before us, and it is better to have a fnture than a "past."

'This view is enforced by the growing community of interests thronghont the world. It is the capital and enterprise of the Atantic slope that has been the basis of Chicago's wealth, as it is the wealth of the Old World that has been for fonl centuries developing the resonres of the New and laying the fomdations of its greatness. This is a lomage to its freedom, and an invitation to its suplemasy. 'The improvements in the art of war are making National quarrels impossible, for' war itself shall be destroyed. 'To this New York has long griven a pledge in its undefended harbor, lying open to the sea.

Count SHouvalofe happily said of this country in his 
speech at the recent banquet given in honol of Minister Willian Water Puesps, at Berlin, that we "stand "alone among the great powers as wanting nothing and "fearing nothing:"

New York goes beyond the exposition of om own moducts and growth, to think most of the invitution to other Nations to exhibit here their trimulus to us; and they will respond becanse they wish to see the auses of on marelous growth, and to discuss the secret of our prosperiby.

In a broad and far-reaching view, the design and the end of the Exposition is to adrance civilization and the domination of science over mature, to increase the rewalds of labor and the comforts and economies of lile, and to promote freedom and morality. This is the highest idea of human welfare, to free man from the curse of labor that fell upon him in the Garden of Eden.

Human happiness depends upon labol, so we do not seek to be freed from it, but we do seek to make a day's labor bring larger results, to elevate a larger number of people above the starvation point, where the whole day's labor feeds them and no more, to begin accumnlations and create capital for every man. Stean, electricity, new inventions. new railyoads, new channels of trade, new conntries, make labor more productive. 'The value of the wiges of labor has increased during the four centuries past tifty-fold. 'The saving of time, the simnltameousness of knowledge, the rapidity of decisions increases wealth and promotes justice. Peace follows, lor war is one injustice avenging another.

This is the foundation of International friendship and prosperity, through an the peoples of the earth, as National union exists through the states of this country; to participate in their successes and to admit them to ours, to make the field of prosperity as broad as the world.

In stock and agriculture Europe has but little to show us. 
Whe have taken the finest of her hest breeds of cattle, her best vines and fruits, her best seeds and plants, and improved them all. In these respects an exhibit of the West at Chicago would be unapproachable. But Europe can show us articles we do not possess, and achievements we have not attempted. 'These will challenge our' skill and ingenuity to surpass them, as we are wont. 'This will be a greater gain than any feeling of self-satisfaction over on own products. As Chicago asserts, our whole country will be our exhibit, and 110 one can doubt the strength of the impression it will make.

They have works of fine art greatly surpassing ours in their variety, and still more in the power of imagination. 'They are the result of the highest human attainment, and the spring of the purest human happiness. They have these arts applied to buildings, interiors, decoration and furniture which we are fast learning. They cun show surpassing excellence in the most ponderous machinery and in the most delicate; in metal work of every kind, perfect in strength and in exquisite design; in the adaptations of electrical contrivances; in all the fabrics of the loom down to the invisible lace; in gems and precious stones: in books, music, photography; in wines and perfumery; and in almost every industrial art. These must be brought under the eye of onl own skilled mechanics and inventors. For them the Patent Office Museum and the fair's of the American Institutes are far from being enough.

New York is thoronghly prepared for the Exposition. The dissensions in Chicago, when they begin to select a site, are yet to come, but they have not yet been enough in earnest for that. Here we quelled the rivalry of all the property owners by disregard of their claims and selecting the very best. On Bloomingdale Heights with Riverside and Morningside Parks there is abundance of room. It rises high above the waters of the Hudson River, with steep declivities on three sides, and has an area of 184 acres a vailable for 
bnildings. Mueh additional space can be had along Riverside Palle. 'This site is now beyond further question.

The Central Park affords two sites, long ago set apart for Museum building's, in each of which sections of the museums have been erected. That of the Mnseum of Natural History has 20 acres and of Art 18 acres. 'These buildings the City propose to expedite and complete. 'logether they will supply, for the priceless exhibits, 50 acres of flooring in fire proof buildings, and cover one-hall" of the ground requirea for buildings by the estimate of the Committee, with the open park around them. 'The other' hall', or three times as much, can find ample space on Bloomingdale Heights. There is another site in Central Park of 20 acres, set apart and partly occupied as a Horticultural Hall and Garden, which can be completed.

For broader areas, for temporary structures, 60 acres next north of Central Park and adjoining Bloomingdale Heights on the east can be had. If we wish to attract from Chicago the cattle yards and "punkin shows," we have along the Harlem River, within three miles, a thousand acres accessible and available.

Central Park is in the City, and more than half surrounded by houses. Bloomingdale Heights is at its northwest corner between Riverside and Morningside Parks, and accessible by half a dozen lines of surface cars, as well as the Elevated and Hudson River railroads and the Hudson River stemboats.

The financial plan of the City is adequate. The City authorities are ready to expend fifteen millions in land and buildings. 'This will complete the two Museums and the Horticultural building in Central Park, will purchase for a park the land on Bloomingdale Heights and erect the buildings there, and will provide all the land needed for temporiry buildings. The guarantee subscription of Fire millions for working capital will, with such aid as may be had from the State or Congress, suffice for the rest. The cautious movements of New York are an assurance of final 
success. Our subscriptions represent all cash and not paper, worth "two per cent." or less.

Foreign visitors will land at this City. There is no better place for the exhibition of their art works and manufactures. 'They can be lauded on the fair grounds. 'There is no more central place in the country to collect our own. for all purposes, except agricultural products, it suffices. 'The fleets of all nations and their yachts will be here. They cannot reach the "unsalted sea." There will, in any event, be a great gathering in this City, and for all the ends of an International. Fair, this will be the site. To ask them to go to Chicago, wonld be the same as if Chicago located her national fair at Waukesha, becanse of the subordinate advantage that there was the spring from which she brought her bottled drinking water.

In every stranger here there will be the desire to see the country, its rast distances, its newly grown cities of a million, not yet so "old as a man's life." Chicago will be their. Mecca. But still these visitor's will prefer to live in New York, and to be fed at the greatest place in the world for the excellence and variety of its market. There is to be but one fair, and New York is the place.

To the impartiality of the citizens of Lonisiana we can trust this question with confidence in a just decision. At the seat of an empire which commands the whole Mississippi Valley, from the Alleghany to the Rocky Mountains, including Chicago, and at the point on your grand river leached by the early Spanish explorers who followed Columbus, a commercial rival of New York-each New in name but old in history and cosmopolitan in spirit-independent and chivalric-you are the just umpire in a contest which is alousing the whole country. If you fail us, our only appeal will be to the beantiful women of New Orleans.

Yours respectfully,

W. E. D. STOKLS. 
Bỵ permission from the Cnsmopolitan Maguzine, December, 1859

\section{NEW YORK'S CANDIDACY FOR THE WORLD'S FAIR OF I892.}

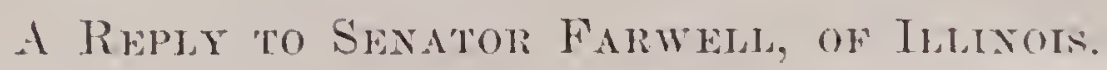

In the same Magazine of November, 1889.

BY WILLAa Waldorf Astor.

I am invited by the management of the Cosmopolitan to reply to an article recently published in that journal by the Honorable Charles B. Farwell, United States Senator: from Illinois, advocating the claims of Chicago to the proposed Columbus Exhibition. In presenting a few points in favol of New York, 1 wish to begin by declaring myself cordi. ally of the honorable Senator's opinion that the emulation between the two cities should be conducted without bitter. ness or partisanship, and only in a spirit of broad and liberal riralry.

'The nine pages occupied by the Senator are more than half taken up with illustrations of streets and parks and momments, and, of the text, the greater portion is culled from the note-books of travelers and writers, for which, since he ador,ts them, he is responsible equally witl any part of his argument. Less than one-quarter of the nine pages is covered by his own words-as though he had found difficulty in employing his pen to divert a momentous and historic celebration from the metropolis of America to a provincial city. 'Those of his sentences which are not bolrowed embody three propositions in support of the claims of Chicago :

Fivst, That it is easy of access to farmer's.

Second, That it is the choice of lumber men, iron men and machinists.

Third, 'That several previous exhibitions having been held in the East and Sonth, it is now the turn of the West. 
The Senatol: dismisses very lightly the advantages to be derived from the maritime position of New York, and his argument is interesting, in that it reveals the scope of the celebration he has in view, and makes it as a National, and not an International, Exhibition. Me thinks the first and last consideration should be the convenience of ou: western population. The ratio of foreign visitors and exhibits would, in his opinion, be small, and doubtless this anticipation will be sustained if Congress decides upon an inland location. 'The Senatol' proceeds to fasten upon his conception of the Colmmbus Fair a distinctively agricultural character. It is the interest of the stockbreeders that chiefly appeals to him. and he designates the products of the far'm as first entitled to the best opportunity for display. One readily hears in his utterance the voice of Illinois, when he claims the Exhibition because the Secretary of Agriculture pronounces Chicago "the centre of the greatest agricultural and stock-raising region on earth" ; and the solemnity of the semator's discourse is relieved by the incidental facetionsness of the declaration that an eastern man should visit Chicago innually, to be "inoculated with mnrepressed enthusiasm."

New York will with difficulty concede these things lie so easily takes for granted. Our geographical situation is not to be disposed of in the careless sentence of a magazine article. If the Senator will tum from the map of Illinois to the map of the United States, he will observe that New York is the point from which all lines radiate. We communicate eastward with Boston and New England, and northward with Montreal and Canada. Westward stretch the great Pacific roads to California. Through New Jersey run railways that spread over the Gulf States from Florida to T'exas. And seaward come to us the ships of all comntries-from Enrope, and from the Orient, and from the South Sea. New York is the point of contact between America and the nations of the earth. It stands in the gateway between the New World and the Old. It is the 
place to which three-fourths of onr commerce is drawn, to which the traveler visiting this hemisphere directs his course, and which, in the thonghts and writings of foreign communities, be they of high or low legree, stands as the type and centre and head of everything pre-eminently American.

The Senator from Illinois differs, however, with the majority, and quotes a statement that "Chicago is the one purely and distinctively American city on this continent." In what, then, does it differ from the others? Is Lancashire more English than York, or Calais more French than Lyons? Or how is Chicago more distinctively American than st. Louis? Serenty-five years ago the site of Chicago was a wilderness as silent as Manhattan Istand when Hudson first beheld it. Like San Francisco, its wealth came in a few yeurs of sudden prosperity. Tike Boston, it rose superbly from its ashes. Like all the rest of $11 \mathrm{~s}$, its splendor is of recent growth-more recent, indeed, than that of any other.

'The Senatol further advances the architectural magnificence of Chicago's private residences as a logical reason for placing the great Exhibition within their ameole. Chicago is the "London of America," possessing "metropolitan imperialism," and worthy of the designation of "the young griant of the prairies." Its houses, he dectares, are "palaces." We know them well, those palaces, all of which were built with borrowed money, and most of which to-day are mortgaged from cornerstone to skylight. TVe know them well, those palaces, where every sign of wealth abounds, and where the front door is opened by a housemaid. Tre know them well, those palaces, whose occupants are "all out on their doorsteps," as they used to sit in New York seventy years ago, when our "palaces" were built on twenty-five-foot front lots, and when social hife was primitive in the extreme.

We, in New York, conceive the significance of this Exhibition to be something higher than lumber, iron and live 
stock. We have not in mind the agricnltura] show the Senator meditates. IVe aim to make it an historic exem plar of the last four centuries-to illustrate what has been achieved in civilization since the discovery of America. And as that discovery led on to still vaster explolations, to the IIorn and the Cape ronte, and through all Chinese Walls of Asiatic intolerance, and northward toward the frozen Pole, and southward across the forests of Africa, so would we bring to this Lxhibition, by all routes, and fom the remotest barbarism as from the most accomplished civilization, the distinctive and characteristic feature of each.

When Colnmbus steered from Palos, he launched, half conscionsly, the entire human race upon an intellectual sea whose nltimate shores have not yet been explored. Behind the star-guided track of his ressels lay the ignorance, the fendalism, the bigotry of the Middle Ages; before him, unseen by the material eye, but divined, we may believe, by his spiritual vision, stretched realms of adrancement and discovery in strange and marvelous paths of learning. His achievement aroused the minds of men from the torpor of dark and crnel centuries, and liberated human thought, and awoke the genins of invention, and prepared the way for religions toleration, and led to emancipation from the ahsolute rule of kings. 'Those are the greatest benefits that have ever blessed the race, and these thoughts underlie the material progress which is their natural exponent. From them sprang literature and exquisite refinement in every alt, and the trimmphs of science, that fill this age with marvels as wondrous as the visions and dreams of the alchemists of old.

If the Colnmbns Exhibition be merely an ordinary display of products and manufactures, it will fail of that suggestive meaning from which it should derive its profonndest import. Its grandest purpose, and one far beyond mere material prosperity, should be to mark the progress made in the civilization of all mankind since the discovery of this 
comtinent to the present day. In that year, 1892, we shomld gauge the human intellect by its achievements of the last four hundred years. This Exhibition shonld display the advance made by every comtry in the dhief splueres of thought and labor that have liberated and instructed and ennobled the human lare. It shonld compare the fifteenth with the nineteenth century. It shomld contiast the impotent, medianisms of the past with the marels of beant? and power and delicacy of the present. It should station. in view of the mighty steamships that ross and recross the ocean, the caravel of medireval thaly, the galleon of ancient Spain, the pinnace of Raleigh, the Haly Moon yacht of Hendrick Hudson. Tt shomld place beside the pictured missals of monkish aloisters the printing-press that distribntes each day's news from every part of the world. Besides the post-chaise of H'anklin's day, which carried the mails in six weeks from Boston to Philadelphia, should stand one of the locomotives that flies at train in six days from ocean to ocean. It shomld lay the wooden letter-type, which was the mechanical narvel of the time of Colmmbus, with the electrical appliances which are the wonder of our own. Within it shomld be gathered trpes of life and industry from erery section of the Union. Within it should be seen the homes lamiliar to every part of this continent, and recalling every arge -the Southern plantation, the backwoodsman cabin, the puritan's house of the seven grables, the gold miner's camp], the Canadian trapper's lodge, the Dutch rottage of Diedrich Knickerbocker, the wigwam of the Iroquois, the Californian adobe, the ice hut of the Esquimax, and back even to the semblance of the monnd-builder's inclosure. 'To such an Exhibition should be brought representatives from every tribe and nation of the inhabited globe. And from such gathering as this men might study the possibilities of the future by the teaching of the past. In looking back across the strifes and follies and crimes of olden times, they could meditate the great lesson of the comity 
and forbearance of one nation toward another, and seek ways of more perfect justice, and study the paths of wisdom and moderation.

For over a century New York has held not merely a material, but an historic, supremacy. The history of New York, more than that of any other city, is the history of the progress and development of the whole country. In it George Washington was inangurated. At the close of the Revolutionary War it was chosen to be the first capital of the infant nation. In population, in wealth, in manulactures, in pnblic works, in commercial relations, it is the capital of the Union to-day. Chicago is an inland city, fir from the tonch of foreign countries, surrounded by its lumber, iron and live stock, and nuknown to Europeans, except for a quizical curiosity which its extraordinary growth inspires; and from the circmmstance that they read of it as a refuge for their own political outcasts, who go thither, not as inhabitants, but as incendiaries, to establish in it their socalistic fraternities, to manufacture anarchist bombs, and to hiss the American flag in public.

To render the Colnmbus Exhibition successful, it is indispensable that the interest of foreign lands be enlisted. Does the Senator think it nothing to ask French and English manufacturers to send rare and costly and perishable wares across the Atlantic? Does he think such exhibits will be augmented in number and value by alding to the sea voyage the risk and delay and expense of land transportation? Bearing in mind the relatively small exhibits sent by England and France to Viemna, by reason of the inconveniences of transportation, will they be more likely to send to Chicago? Is it not evident that the bulk of exhibits sent to the shore of Lake Michigan would be infinitely less than that sent thirteen years ago to Philadelphia, beside the ocean? With what are manfactmrers abroad to be tempted? Certainly not with the prospect of advertising their merchandise, for already Americans throng among them and are the most extravagant buyer's 
in every Enropean market. Nor will prizes and awards allure men who have already reaped a harvest of medals and honorable mentions. No, the sole incentive that will bring foreign exhibitors is the keen rivalry of their own immediate competitor's; and as, even then, the motive must be very urgent, and the risk and cost and dilliculty rery slight, it may be confidently asserted that the mecessity of breaking balk between the place of shipment and the exhibition site, would be to them a latil objection.

'The Senator's argument in favor of Chicagro rests upon the mistaken premise that an inland and prosaic city can be made to appear accessible to distant comntries, and attractive, and of central importance. In the characteristics he ascribes to the projected Lxhibition, he pictmres a county fair on a vast scale, and doubtless in accord with the ideal and interest of the State of Jllinois. But that is all-and that is not enough. For this anthem the note of a single instrument, howevel shrill its piping, will not suffice. Only the full concert of all nations, and the strength and sweetness and inspiration that all humanity may bring, can commemorate the debt that all humanity owes to Christopher Columbus. 



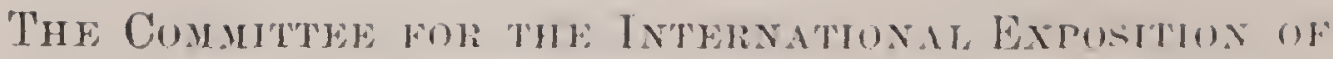
189\%, OF TII CITY OF NEW YORK.

COMMIT TEE ON LEGISLATION.

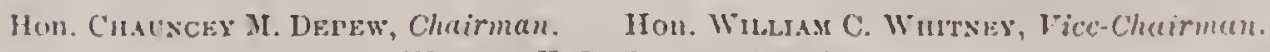
WILJ.JA E. D. STohEs. Secretury.

At the Board of Trade of Providence, Rhode Island, there was held on the sth October, 1889, a meeting of the mercantile and mamufacturing interests of the State, to ascer tain the feelings of the state in regard to the location of the International Exposition of 1892. His Excellency Governor Herbert IV. Ladd, who presided, had invited the Mayor's of New York and of Chicago to present the claims of their cities.

In response to this, the Mayor of New York referred the invitation to the Committee on Legislation. Mr. Depew, the Chairman, sent the telegram, and Mr. Stokes, the Secretary, sent the letter which follows :

New York CrTy, Oct. 8th, 1889.

\section{To His Excellency Goverior LADn,}

Providence, Rliode Island:

'The Mayor has referred your telegram to the Committee on Legislation, and I am just in receipt of it. We find it impossible for a representative to be at your meeting to-day. New York is deeply in earnest and will use every effort to secure the Fair and to make it a success. Our. Secretary, Mr. Stokes, has sent you a communication. We confidently rely on the assistance of Rhode Tsland in making the Fair at New York the greatest exhibition ever held.

Chaunchy M. Depew. 
NEW YORK, 146 BROADWAY, October 7th, 1889.

To His Excellency Goveraror Ladd,

Providence, R. I.

Sili :

Your telegram to His Honor Hugh .J. Grant, Mayor of this City, inviting him to present at the meeting to be held at noon to-morrow, at Providence, the claims of New York, as the location for the Exposition of 1892, was recrived to-day, and was referred by him to me, as he telegraphed to you.

I legret that I am not able, at such short notice, to arrange this evening to attend yon meeting in person. I will, however, on behalf of the Committee on which I am placed by the Mayor: endeavor briefly to state to you the reasons why the Exposition of 1892 should be held in the City of New York.

The chief reason is found in the fact that the proposed fair is to be ar International one. Tt should, therefore, be held at the city most accessible to foreign comntries. No other place meets this condition.

New York is the greatest seaport of the continent, most frequented by steamer's and with the largest number of arrivals and departures of trans-Atlantic passengers. It is the commercial centre, and in financial and business affairs it is the heart of the continent. It is, as well, the greatest manufacturing city, and all this can be aflirmed without disparagement of any other city.

Of the whole continent, extending 3.000 miles from the Atlantic to the Pacific, more than one-third of the population is contained in States within 400 miles of New York. Within ten miles of the city there are about three and onehalf millions of people. It is the most accessible point on the seaboard, by railroad and water transit, and is the terminus of every railroad. 
It has the langest hotel accommodation for travelers. These considerations hare lolce because the success of the Exposition depends upon the number of risitors who daily seek andmission. This number depencis on local density of population and accessibility to those who travel to attend it.

The experience of Europem nations in managing and locating their great fairs enforees these views.

They have located them at their great centres of population and travel, at Paris, London and Viemma, and nerel elsewhere.

New York City is known all over the world better thin any other city of this country, and as well as London or Paris.

It has come to equal, and in some respects smlpass them among the great cities of Christendom. 'The site selected for the Fair has more than ample area and is along the border of the IIudson River, where vessels can land at the Fair grounds in deep water, and this water communication is not broken by a shallow or a bar for ships of a heary dratit to all the remote shores of the ocean. This means cheap freight and charges for all the exhibits sent to the Faril. 'The site rises from the water border to a round hill 150 feet in height, with a flat top, admirably adapted for public buildings. There is no such site within the limits of any city in this conntry or in Enrope. It commands a view of forty miles in every direction, from the momntains to the sea. It is surionnded by beautiful parks.

For healthinlness and cool smmmer breezes over the broad Indson River, and from Long Island South, it is the pleasautest spot in the whole Atantic slope. New York City itself is the finest exhibit this country has to show. Not only does the city meet all the conditions required for the location, but these conditions exclude every other city. The site has been determined and the financial plans will be well matnred and acceptable, for the Fair is to be International and not a Fair of this comtry or any section of it. 
We celebrate the discovery by Columbus; lie crossed the sea four centuries ago; he reached the continents of North and South America; he did it for the countries of Europe, whose explorations forthwith extended over the whole earth. It is not simply an affair of our country, but for the whole world. And for this, not we alone, but all mations and peoples unite to do him honor. 'The Fair must of necessity be International and the only location is the chief city of the New World which he discovered.

Yours very respectfully,

$$
\begin{array}{r}
\text { W. E. D. STOKEs, } \\
\text { Secretary. }
\end{array}
$$

'The response from Chicago was by Mayol Dewitt C. Cregier::

Cuncag(), 7th October; 1889.

G(NVRNOR LADI):

IVe respectfully submit the following questions and surgestions :

Fust. - What are the indispensable requirements of an eligible location for the World's Fair?

secost). - Confining on question to cities of over al million inhabitants, has any other than Chicago so cool, comfortable and wholesome a summel climate: Can any offer to millions of visitors in the dog days an equal immunity from sum stroke and disease.

'THRD.-Has any so limitless a supply of fresh air and fresh water as the works now in process of construction insure to Chicago from the great lake which is at once her. refrigerator and her fountain.

Fons'ru. - With her eleven lundred and sixty hotels and thirty-eight railroads, can any offer equal hotel accommodation and railroad facilities, with assurance from hotels of no increased charges, and with like assurance that inland 
transportation of foreign exhihits will not exceed the cost that will be incured in the unavoidable braking bulk with extra carting and handling elsewhere.

Fnoru.-As IVorld's Fan's and national celebrations have hitherto been held in the extreme East and Sonth, is it not the West s tum now by the rnles of rotation and by erery consideration of comity and fairness.

Sixtr. - Why shomld not all Anerians and attending foreignels have an opportunity of judging of the conntry as a whole. not by a mere inspection of its onter edge. hut by coming into its body and witnessing its phenomenal snceess.

Sirmoxtr. - Why should they not all come to its greatest inland city; a fair in itself as a marvelous growth of a few yent's from a frontier camp to a Netropolis of inmeasmoable destiny, and see for themselves whether it is true or false that she is the focms of the greatest inland commerce of the world. That she has in fact the finest group of busiuess structures, the most extensive park system the largrest and nost beantifnl drives, including that named after and worthy of Sheridan, to be found on this continent, and in the absence of an Eiffel tower, ancther structure, the Auditorium, of several times the cost and incomparably groater ntility.

Erintr. - Why is it not peculialy appropriate that the Columbus Exposition should be distiuctively and grandly American?

Niner. - Why should not the nation bial this great young wity, covering one hundred and seventy-six square miles, a hearty God speed in the great enterprise with which it grapples. As the West consumes a great proportion of Rhode Tsland's mamufactures why should not Rhordo Island be conspicuous in presenting her manufactured products to her western consmmers. A small State, yet hrl' 
products being vast, enables her to grasp the situation and take a truly broad and national view of the question.

Please defer action for a week and we will send a representative who will present facts of greater importance bearing upon this subject. Answer.

\section{Dewhte C. Cregher.}

In accoldance with this request the meeting was adjou'ned to 'Tnesday, 15th October, 1889. 'T'o this meeting the Committee on Legislation sent the following letter:

New York, 14th October, 1889.

To his fercellency, the Hon. Herber'I W. LADD, Govermor and Chairman, Providence, R. I.

SIR:

We recognize the wisdom of the adjommment of your meeting to consider the location of the Interuational Exposition of 1892, and your courtesy in re-opening the discussion of the claims of Chicago for the location.

Besides the considerations we had the honor to present to you at your first meeting, we will add a few further suggestions.

No one is pronder of Chicago than the people of this city. It was a great citizen of New York, who, year's ago, said "Young man, go West, and grow up with the comtry." They went ; and so Chicago grew up to be great in obedience to New York. The result is a crown of homor to her. Many of her foremost citizens went from New York. Her men of wealth and intelligence, when they retire from active business, come, many of them, to this Metropolitin and Cosmopolitan City to add to its renown. 'The bond between us is growing every day and can never be severed.

The elements of Chicago's greatmess, recounted by Mayor Cregier, are justly impressive. Every man will uphold 
them as he would the praises of a beantiful sister. Her salubrity, her water works, her hotels, her railroads, her superb buildings, her parks are marvelous, and she is undoubtedly the site for anything that is, as she claims, "to be distinctively and grandly American." But they do not reach the point of making her the focus of Internationality, nor do they claim it.

New York has like elements of city growth and proofs of prosperity : but as New York compares itself with London and Paris, cities rich with the expenditure of centuries and the embellishments of renowned art, it strives modestly after the finest and severest results in building, in the perfection of its adaptations to business and domestic life, and in landscape art as shown in its parks, with a subdned ambition to become the best modem city, not of this country, but of all christendom. Its commerce is not because of its own efforts, but because the world of ships crowd into its himbor. Tis railroads come here to meet and participale in this commerce, and as the great New Yorker whom we have alleady quoted, Horace Greeley, whom Chicago also renerates, said when he was shown the extent of her great railroad systems, "All these roads have one terminus in New Tork."

These things make New York the international point of this continent. There are few grounds on which to dispute the claim of Chicagro to be "the focus of the greatest inland commerce of the world," if that were the question. if this were a mational fair, if it were an affair of this continent, but this is to be an Internalional Exposition and it is the feature of internationality that gives the preference to New York. What the whole country has to do with intemational affairs passes into and is received from New York. Its growth is a natural concentration, and when foreign visitor's with their goods arrive here, they will say, "Neplus ultra," not even for the attractions of beautiful Chicago.

In the May Centennial of this year people poured into 
this city, ovel a million and a half of them, and not one lacked food or shelter; nor were the accommodations of the hotels exhausted. These are matters of only ordinary every day concern.

Amid a resident population of three and one-half millions the adrent of a few hundred thousand more does not put us or them to the shightest inconvenience. The number of passengers carried by our city cars is daily counted by millions.

Onr Summer climate so closely resembles that of Rhode Island, and is so purified by the sea breezes, that this is one of the farorite spots on the Atlantic coast as a resort for. visitol's from all the IVest, who come even from Chicago to New York and Newport to

"Sate them with kisses of the broad Atlantic."

Our nearby resorts along the Jersey coast and on Long Island are healthfinl and cool in mid-summer, beyond comparison, and capacious enongh for hundreds of thousands. By our new aqueduct on water supply from the pure mountain springs in the Highlands of the Hudson will be quadrupled, and for a "refrigerator" we have on one side three thonsand miles of the great ocean, and on the other the mountain breezes of the whole range of the Alleghanies and Catskills.

Even without a Fair, the moment a foreignel' who comes here on a visit starts inland to see the country, Chicago as "the centre of our great inland commerce" will be the first attration.

New York will not be behindhand in financial support. Its leader's in finance are many of them men retired from active business, who move cautiously and surely.

The City authorities have proposed to expend fifteen millions in land and buildings. The proposal for a popular subscription, started at five millions, was so warmly welcomed that it is assured as soon as the Finance Committee 
announce the terms on which it will be received. This is a sound basis, and further finanrial aid is in readiness.

The Worlḑ's Fair will be held in New York. near New England, the seat of ingennity and the birthplace of mechanical inrentions, which have benetitted the whole world, lightened the burdens of the laboring classes and increased their earnings one-hundredfold. These have proved to these United States what Columbus trusted the discovery of the New World would be to Spain "a sonree of much wealth." As your illustrions Bumside said of his men, that he conld "always rely upon them," so we now say of Rhode Island.

If we were to have a State Fair and we wished to make it a great success would we locate it at Albany, becanse it was our Capital, or locate it where the greatest number ronld most conveniently attend and be most comfortably sheltered and fed? Did Fngland locate her Internatiomal Fair at great Birmingham or at London? At which place would it have been the greatest financial benefit to her whole country? The Exposition at Vienna was a dismal failure because it was too far inland.

Starting from the Battery on a level but little above the tide, as one goes np town in New York higher levels are reached, one above the other-Murray Hill, Lenox Hill, the heights in Central Park and the clifts of 12iverside. This progressive ascent attains a summit at Bloomingdale Heights, seven miles from the Battery, and 150 feet high. This is the Citadel of the city, for above it the hill falls abruptly, nearly to the river level in Manhattan Valley. Here was fought the decisive battle of Harlem in the War of the Revolution.

The region west of the Central Park is not surpassed in natural beauty by any suburb of any city, and it is filling with the finest residences, so that even families from Chicago come to dwell there and to enjoy life, for its pure and sootless atmosphere. Its growth and beauty are the 
marvel of New York. It is a high plateau ascending grarlually to this summit of Bloomingdale Heights, which we have chosen as the best we have for the site of the Fxposition. Its adaptation, as well as its grand beanty, are unsurpassed. 'This hill commands a view of the broad Hudson, where there is room for the anchorage and parade of the grand fleets of Spain, and of all the other nations which, it has been already announced, will yisit us.

When the Columbus tower shall be erected upon it, the visitor will scan the broad Atlantic for a quadrant of the horizon, the ocean that Columbus traversed, ret we do not claim that he can see the track of his "Caravel." In our broad sheltered harbors a thousand or more yachts will ricle in readiness for the great "International yacht race for the 'Columbus Cup'-a challenge to the world."

When the people of Rochester showed Daniel Webster the falls of the Genesee he told them that no people who had a water-fall 150 feet high erer lost their liberties; nor can we when we have this hill for a site cver lose the fair ; nоr can any man, when he stands upon it, vote against it.

The strangers who come from the distant cities of the wolld; one who at home stands at the Castle at Edinburgh - the Miniata at Florence-the Church of San Martino at Naples-the Pincian Hill at Rome-or the ter'aced palaces behind Genoa, will all unite in saying that this hill is the worthy Acropolis of a metropolitan city; while to the dwellers in the lowlands about London, or Paris, or Berlin, or to those who live on the beautiful Western prairies, it will be a revelation.

'The Hudson River at its feet was the inspiration of the sweetest poets and writers of our land, of Irving, Bryant. Hilleck, Drake and Poe, and through them its beanties liave found international fame. They unite with Halleck in

"The esteem

" We bear this fairy city of the heart."

Columbus was the precursor of the bold sailors who circummavigated the world. What he and his Spanish fol- 
lowers did was for Spain, for the cross and for gold ; and for centuries his newly discovered land belonger to Spain. England and Molland did the same thing for freedom, for trade and for dominion. From the European point of view. the honor of the discovery of the New Morld belomged to the Old, as to them belonged the daring and the perils of their explorations and settlements, and this honor ther will not forego. From the North Sea to the Mediterrancan. they connt it as their glory, from which we, their sons. are receiving the inaterial benefits. They will come here to receive their reward in honor, as they see ours in prosperity. Fven the poor Italian in the streets will be treated, in that great day. with brotherly reverence. This sentiment is not to be disregarded. It is the spirit in which the internationality of the fair subsists. Hence will start the blessings which will again circumnavigate the globe for the good of all nations, and bind us anew as one in heart, as Columbus made the union of men possible over the face of the unknown and undiscovered earth.

Were Colnmbus himself once more alive and permitted to-day, after four hundred years, to visit one only of the great cities of the Western Hemisphere, which one wonld he be most desirous of seeing? Would it not be the city of the greatest population, the greatest wealth, the greatest manufacturing, commercial and shipping centre? This is true of everyone else. A location for this Exposition of 1892 must be selected which is most accessible to and most representative of all the Americas, North, Central and Sonth.

There are many millions of our Western prairie citizens who have never seen a mountain or the Atlantic Ocean, and to them, as to ns, the sight and inspection of even one of our great ocean steamers is a marvel in itself.

Columbus found what he thought to be the "far Cathay." That is the nearest approach he made to Chicago. He never reached it, for his description does not fit. 
He says: "I found only a few hamlets, with the inhabi"tants of which I could not hold conversation, because "they all immediately fled." "Then he describes his trade with them "Whether it be something of value, or of "little worth, that is offered to them, they are satisfied.

"They even took bits of the broken hoops of the wine "barrels and gave, like fools, all they possessed, in "exchange, inasmuch that I thought it was wrong and for"barle it." Certainly this was not Chicago.

Witness how he closes his narrative of the discovery, which is to be celebrated not by us but by the whole world. This is the spirit to which New York most heartily responds.

"But our Redeemer hath granted this victory to our "illustrious King and Queen and their kingdoms, which "have acquired great fame by an event of such high "importance in which all Christendom onght to rejoice and "which it ought to celebrate with great festivals, and the "oftering of solemn thanks to the Holy Trinity, with "many solemn prayers, both for the great cxaltation "which may accrue to them in turning so many nations to "our holy faith, and also for the temporal benefits which "will bring great refreshment and gain, not only to Spain,

"but to all Christians. Thus briefly in accordance with "the events."

This stamps its internationality.

Yours very respectfully,

W. E. D. STokes, Secretary. 
Governor LAnD presided at the meeting on the 15th October.

The foregoing letter of Mr. Stokes was read as the argument for New York. Ton. Thomas B. Bryan, of Chicago, in an eloquent and forcible address, presented the claims of Chicago; Alexander D. Anderson those of Washington.

The following telegrams from Mayor Grant and ex-Senator Platt were read:

\section{NEW York, October 15.}

\section{His Excellency, Governor LADD:}

The people of New York desire that the World's Fair of 1892 should be held in their City, and hope that the people? in your State will aid them in securing it.

HUGH I. GRANT.

NEW York, October 15.

GOVERTOR LADD :

New York looks to Rhode Island for her support and assistance in making the International Exposition of 1892 , in New York City, a grand success. Our secretary. Mr. Stokes, has sent you a communication.

Thonas C. Platito.

J. N. S'tarkw Eatrer, President of the Board of 'Trade, then offered the following, which was adopted:

Resolved, That an Exposition in 1892, in honor of the 400th anniversaly of the discovery of America, is the best manner in which to celebrate so important an historical event.

Resolved, That the success of such an Exhibition must depend upon its exhibits and its patronage.

Resolved, That New York City, being the largest manufacturing City in America, is the centre of all the varions industries whose exhibits wonld contribnte to make an exposition inviting. 
Resolved, That the agricultural and mining exhibits being more novel to Eastern people, would be a greater attraction in New York City than anywliere else, alike from the interest capital would take in it and the larger number of people.

Resolved, That New York City is the centre of a large population which can visit the Fair and return in one day, thus insuring a success.

Resolved, 'l'hat New York City from its harbor and commerce is known all over the world as is no other American city.

Resolved, 'That Rhode Island, while fully cognizant of the claims of Chicago and Washington, believes that the City of New York has the most commanding advantages for success.

Resolved, That Rhode Island casts her rote for New York for first choice and Chicago for second choice, and will assist, as far as lies in her power, to make the Exposition worthy the event wherever held.

Resolved, 'That his Excellency the Governor be requested to transmit copies of these resolutions to the President of the United States and members of the Cabinet, the President of the Senate, the Speaker of the House, the Governors of the various States and Territories, the Mayors of the principal cities and the presidents of all commercial bodies.

"A great mass meeting of Rhode Island citizens was "held in the Capitol of that State yesterday. New York "was enthusiastically endorsed as the site for the Exposi"tion of 1892.

"If Providence be with us, who can be against us?" New York Herald, Oct. 16, 1889. 